\title{
مئس المؤته
}

\section{كلمة الأستاذ الدصتور / صالح أهد شاصر}

السادة الحضور جميعاً ، معالى أ.د الهلالى الشربينى وزير التعليهم السابق ،

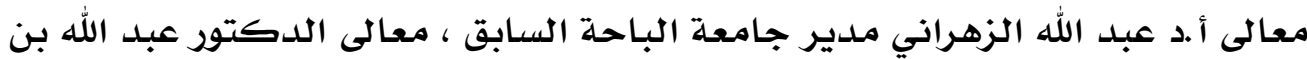
صالح الشتيوى رئيس مجالس أمناء كليات بريدة والمشرف على كليات عنيزة السعودية ، سعادة العمداء وأعضاء هيئة التدريس وأعضاء البرلمان ، والهيئات الممثلة للقطاعات

$$
\text { والمؤسسات ذات العلاقة والشراكة في التنميلة . }
$$

السلام عليكم ورحمة الله وبركاته تشرفنا اليوم بلقاء حضراتكم فى هذا المؤتمر

العلهى الذى يناقش العديد من القضايا والتحديات المرتبطة بالتكنولوجيا المتكاملة والتى أصبحت جزء لا يتجزء من عوامل وعناصر التنمية المستدامة فى مصر والوطن العربى ، وبخاصة المرتبطة بالتعليم والتدريب وتنمية المهارات والتفكير لدى الأفراد ، حيث يناقش المؤتمر العديد من الموضوعات من خلال البحوث وأوراق العمل والتطبيقات التكنولوجية المرتبطة بها ، ومن الجديد فى هذا المؤتمر أن يبدأ بإلقاء الضوء على

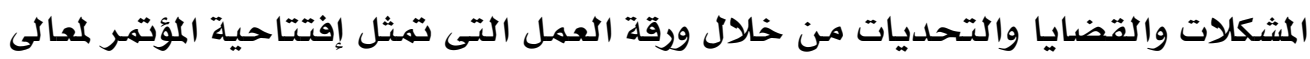
الأستاذ الدكتور / الهلالى الشربينى الهلالى وزير التعليم السابق ، وقد جاءت أوراق العمل متخصصة بشكل تكاملى لتعالج محاور المؤتمر المختلفة ، كذلك يأتى هذا المؤتمر ضمن التصنيف الدولى للشراكات الدولية بالحضور واوراق العمل من بعض الدول الشقيقة وعلى رأسها المملكة العربية السعودية ، حيث يحضر معالى الأستاذ الدكتور عبد الله الزهرانى مدير جامعة الباحة السعودية السابق ، ومعالى الدكتور

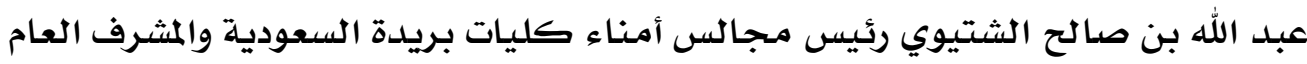
على كليات عنيزة ، كل التحية والتقدير لوفود المؤتمر سعادة العمداء وأعضاء هيئة التدريس وأعضاء البرلمان والجهات الأخرى ذات العلاقة والشراكة فى عمليات التنمية 
المستدامـة ، كل التحية والتقدير لسعادتكم جميعاً على تشريفكم وجهودكم العلمية التى ثمثل ثراء فكرى وأجندات حلول وتطوير للتكنولوجية المتكاملة وتوظيفها بها يحقق التتهية على مستوى مصر والدول الشقيقة والسـلام عليكم ورحمة الله وبركاته ،،؛، 